\title{
Estudio experimental sobre la influencia de la temperatura ambiental en la resistencia del hormigón preparado. Parte 2: implementación industrial
}

\section{Experimental study on the effect of ambient temperature on ready-mix concrete strength. Part 2: industrial implementation}

\author{
J. Puig Montraveta(*), D. Masó Gamell(*), J. A. Ortiz Lozano(**), A. C. P. dos Santos ${ }^{(* * *)}$, A. Aguado de Cea(***)
}

Recepción/Received: 15-I-09

Aceptación/Accepted: 20-II-09

Publicado online/Online publishing: 1-VI-10

\section{RESUMEN}

El presente artículo constituye la segunda parte de un estudio experimental sobre la influencia de la temperatura ambiental sobre las prestaciones del hormigón, desde una perspectiva industrial. En la primera, se estudió el efecto sobre las propiedades de trabajabilidad y mecánicas, en áridos, pasta, mortero y hormigones, detectando un claro efecto negativo de la temperatura elevada sobre la resistencia, que se suele solucionarcon una sobredosificación en cemento y agua, para mantenerla relación agua/cemento original.En esta segunda parte del artículo, se presentan las bases de una formulación metodológica para llevar a cabo la optimización de la sobredosificación de cemento en el hormigón en climas cálidos, para ser implementada industrialmente en plantas de hormigón preparado. Dicha propuesta se ha aplicado con éxito a escala industrial en plantas de producción de hormigón preparado de Promotora Mediterránea 2, S.A. (PROMSA), considerando que la sobredosificación de cemento en el hormigón puede ser optimizado sin causar detrimentos en las prestaciones del mismo, lo que permite reducir costes de producción sin castigar la calidad del producto.

Palabras clave: hormigón, cemento Portland, temperatura, resistencia a compresión, implementación industrial.

\section{SUMMARY}

This paper is the second part of an experimental study about the effect of environmental temperature on the concrete performance, from an industrial perspective. An earlier article on its effect on aggregate, paste, mortar and concrete workability and mechanical properties reported that high temperature had a clearly adverse impact on strength, which can generally be offset with overdoses of both cement and water to maintain the original water/cement ratio. In this second part of the paper the basis of a methodological formulation is presented, with the purpose of carry out the optimization of the overdosage of cement in concrete in hot climates, in order to be industrially implemented in ready mix concrete plants. This proposal has been successfully applied in some ready mix concrete plants of the company Promotora Mediterránea 2, S.A. (PROMSA), considering that the cement content (overdosage) in concrete can be optimized without any adverse effect in its performance, reason why it is possible to reduce the production costs of concrete without reducing its quality.

Keywords: concrete, Portland cement, temperature, compressive strength, industrial implementation.

(*) Grupo Cementos Molins S.A.

(**) Universidad Autónoma de Aguascalientes (Aguascalientes, México).

(***) Universidad Politécnica de Cataluña (Barcelona, España). 


\section{INTRODUCCIÓN}

Este artículo presenta la metodología seguida y los resultados obtenidos, correspondientes a la segunda parte del artículo titulado "Estudio experimental sobre la influencia de la temperatura ambiental en la resistencia del hormigón preparado. Bases teóricas" (1).

En el citado artículo, se hace mención de los efectos que los factores climatológicos, especialmente durante los meses de verano causan sobre las propiedades del hormigón, principalmente la trabajabilidad y la resistencia a compresión. Asimismo se muestran los resultados de varias campañas experimentales cuyo propósito ha sido determinar la influencia de las temperaturas ambientales extremas sobre las propiedades térmicas, de trabajabilidad y mecánicas del hormigón, así como de morteros, pastas de cemento y áridos. Las conclusiones apuntan al árido como un factor de gran importancia, no sólo por las características específicas de su comportamiento con la temperatura, sino también, porque es el componente presente en mayor contenido en el hormigón (1).

En esta segunda parte del artículo, se presentan las bases de una formulación metodológica para llevar a cabo la optimización del hormigón en climas cálidos, la cual se implementó industrialmente en todas las plantas de producción de hormigón preparado en todo el territorio de Cataluña, obteniéndose resultados satisfactorios en términos de considerables ahorros en el consumo de cemento en períodos estivales (2).

Cuando el hormigón se mezcla, se transporta y se pone en obra bajo condiciones de elevada temperatura ambiental, alta radiación solar, baja humedad relativa y viento apreciable, resulta esencial tomar en consideración los efectos que estos factores climáticos ejercen sobre las propiedades del hormigón. Naturalmente, para minimizar o incluso eliminar la incidencia negativa que todos estos factores pueden producir en las prestaciones del material, es razonable pensar en la necesidad de conocer y comprender la forma en que éstos actúan (3-4).

Los problemas del hormigón preparado a altas temperaturas ambientales ( 35 a $40^{\circ} \mathrm{C}$ ) son consecuencia fundamentalmente de dos fenómenos diferentes, uno tecnológico y otro físico-químico.

El problema de carácter tecnológico está ligado con la relación agua/cemento: es evidente que en condiciones de elevada temperatura la demanda de agua es mucho mayor durante la fabricación y también para la conservación de la consistencia, es muy frecuente añadir agua cuando se procede a la colocación del hormigón ("retempering" en inglés). Algunos estudios muestran que la reducción en la resistencia del hormigón debida

\section{INTRODUCTION}

This paper is the continuation of an earlier article titled "Experimental study of the effect of temperature on the strength of ready-mixed concrete (Part I: Theory)" (1).

That article described the effects of climate-related factors, particularly in the summer months, on concrete properties, primarily workability and compressive strength. It also discussed the results of several experimental campaigns designed to determine the effect of extreme environmental temperatures on concrete, mortar, cement paste and aggregate thermal and mechanical properties and workability. The conclusions identified the aggregate as a highly important factor, not only for its specific thermal behaviour but also because it is the majority component in concrete (1).

This second paper describes a methodology for optimizing concrete in warm climates that has been industrially implemented in ready mix plants all across Catalonia, Spain, with a considerable savings in summertime cement consumption (2).

The effects of high temperature, solar radiation, wind speed and low relative humidity on concrete properties must be taken into consideration when the material is mixed, shipped and cast on site. Naturally, an understanding of the way these factors work is requisite to any attempt to minimize or eliminate their adverse impact on material performance (3-4).

The effect high ambient temperatures on ready mix concrete $\left(35\right.$ to $40^{\circ} \mathrm{C}$ ) is essentially due to factors, one technological and the other physical-chemical.

The technological factor is related to the water/cement ratio: when the temperature is high, much more water is obviously needed to attain and conserve concrete consistency. As a result, water is often added during casting (an operation known as retempering). Some studies have shown that the reduction in concrete 
a la adición de agua es proporcional al incremento del asentamiento asociado a dicha adición de agua (5).

El otro factor importante que hay que destacar y que explica en términos microestructurales la falta de capacidad de desarrollo de las resistencias mecánicas a medianas edades (de 7 a 28 días de curado) cuando la temperatura del sistema supera los valores estándar, está ligado a la cinética de las reacciones de hidratación. La velocidad de las reacciones es mucho mayor, con lo que la formación del gel C-S-H (producto mayoritario de hidratación) se acelera, lo que, a su vez, atenúa de forma considerable el potencial reactivo del cemento en lo que respecta a la formación de silicatos cálcicos hidratados. Las resistencias iniciales aumentan considerablemente cuando se incrementa la temperatura de curado, pero el desarrollo de la resistencia final se ve afectado negativamente (6-9).

Para poder evadir los problemas que conlleva la climatología cálida en las propiedades del hormigón en estado fresco y endurecido, es necesario aplicar algunas recomendaciones prácticas, sin tener en ningún caso una metodología o proceso sistemático aplicado. En este sentido, existen varios estudios y recomendaciones prácticas en la literatura en relación al hormigonado en climas cálidos.

Por ejemplo, la Instrucción de Hormigón Estructural (10) en su artículo 71 "Elaboración y puesta en obra del hormigón", en el apartado 71.5.3.2 "Hormigonado en tiempo caluroso", establece que: "Cuando el hormigonado se efectúe en tiempo caluroso, se adoptarán las medidas oportunas para evitar la evaporación del agua de amasado, en particular durante el transporte del hormigón y para reducir la temperatura de la masa. Estas medidas deberán acentuarse para hormigones de resistencias altas. Para ello los materiales constituyentes del hormigón y los encofrados o moldes destinados a recibirlo deberán estar protegidos del soleamiento. Una vez efectuada la colocación del hormigón se protegerá éste del sol y especialmente del viento, para evitar que se deseque. Si la temperatura ambiente es superior a $40{ }^{\circ} \mathrm{C}$ o hay un viento excesivo, se suspenderá el hormigonado, salvo que, previa autorización expresa de la Dirección de Obra, se adopten medidas especiales."

Por otro lado, las recomendaciones más usuales para minimizar los efectos de las altas temperaturas ambientales normalmente son en el sentido de proteger al hormigón durante la puesta en obra y llevar a cabo un curado más eficiente (11-12) siendo pocas las que se aplican a plantas de hormigón en un proceso industrial.

Entre estas medidas o recomendaciones se pueden mencionar las siguientes: strength due to the addition of water is proportional to the associated slump (5).

The other factor is microstructural and explains the lack of development of mechanical strength in 7- to 28-day old concrete when the temperature in the system exceeds the standard values is related to hydration reaction kinetics. The reaction rate is much greater, accelerating $\mathrm{C}-\mathrm{S}-\mathrm{H}$ gel (majority hydration product) formation. This, in turn, attenuates cement reactivity with respect to the formation of calcium silicate hydrates. The initial strength values rise substantially with increasing curing temperature, but end strength development is adversely affected (6-9).

A number of practical measures must be taken to prevent the adverse impact of warm temperatures on fresh and hardened concrete properties, although no systematic methodology or process is in place. In this regard, the literature contains a number of studies and practical recommendations for pouring concrete in warm climates.

For instance, the Spanish Structural Concrete Code (10), provides in Article 71 "Concrete preparation and casting", item 71.5.3.2, "Pouring concrete in warm weather" that: "When concrete is to be poured in warm weather, all necessary measures will be adopted to prevent mixing water evaporation, especially during concrete shipment, and to reduce its temperature. These measures must be intensified in high strength concrete. This entails protecting the concrete components as well as the formwork or moulds where it is to be cast from the sun. Once cast, the concrete must also be protected from the sun and especially the wind to prevent desiccation. If the ambient temperature is over $40^{\circ} \mathrm{C}$ or the wind is very strong, concrete pouring must be suspended except where special measures are adopted and expressly authorized in advance by the site management."

As a rule, recommendations for minimizing the effects of high ambient temperatures refer to protecting the concrete during casting and providing for more efficient curing (11-12). Very few are intended for concrete plants on an industrial scale.

These measures or recommendations include: 
a) Aumentar la dosificación del cemento (11-12).

b) Incrementar el agua de amasado (11-14).

c) Utilizar aditivos para retardar el fraguado y reductores de agua (13-16).

d) Utilizar cenizas volantes (16-17).

e) Utilizar cementos compuestos y/o modificados (18).

f) Enfriar los áridos (11-12).

g) Actuaciones sobre los procesos de producción y logísticos (19).

h) Optimizar la dosificación de cemento en el hormigón en función de las condiciones ambientales (2).

Considerando que las soluciones " $c$ ", " $d$ " y "f" no resuelven el problema de la pérdida en la resistencia del hormigón y que la solución "e" es inviable a este nivel (por el sobrecoste que supone), se optó por investigar y desarrollar alguna metodología de actuación dentro de la opción " $g$ ", la cual consiste básicamente en realizar un ajuste optimizado en el contenido de cemento y agua de amasado en el hormigón (manteniendo la relación agua/cemento original), basada en la evolución de la temperatura ambiental y la del propio hormigón.

Aplicando este procedimiento se optimiza el consumo de cemento en el hormigón, teniendo al final beneficios económicos asociados a menores costos de producción y también, indirectamente se generan beneficios medioambientales reduciendo las emisiones de $\mathrm{CO}_{2}$ a la atmósfera, teniendo al mismo tiempo beneficios sociales aportando valor añadido a los usuarios de estos hormigones.

Lo anterior es interesante también como una medida para mitigar las emisiones de $\mathrm{CO}_{2}$ dentro de la industria de la construcción con hormigón preparado (20), ya que el cemento representa alrededor del 74 al $85 \%$ del total de emisiones generadas por la producción de hormigón (21).

El objetivo de este artículo es el de mostrar el planteamiento metodológico desarrollado y los resultados obtenidos en su aplicación en varias plantas de producción de hormigón preparado a nivel industrial.

\section{PLANTEAMIENTO METODOLÓGICO INICIAL}

\subsection{Fundamentos teóricos y generalidades}

La metodología propuesta para realizar la optimización de los consumos de cemento en el hormigón en verano se basa en algunos fundamentos teóricos sobre la dependencia de la resistencia del hormigón con la temperatura, la temperatura del hormigón en los primeros instantes y posteriormente, el calor de hidratación y la transferencia o absorción de temperatura de éste al ambiente. Esta política de toma de decisiones a nivel industrial viene a) Increasing the cement dosage (11-12).

b) Raising the amount of mixing water (11-14).

c) Using retarding and water reducing admixtures (1316).

d) Using fly ash (16-17).

e) Using blended and/or modified cements (18).

f) Cooling the aggregate (11-12).

g) Taking measures relating to production and logistics (19).

h) Optimizing the proportion of cement in the concrete depending on environmental conditions (2).

Given that solutions " $c$ ", " $d$ " and " $f$ " fail to solve the problem of the loss of concrete strength and that solution " $e$ " is not feasible on an industrial scale (for the extra cost involved), option " $g$ " was chosen as the most promising area in which to devise possible solutions. The methodology explored consisted essentially of optimizing the cement and mixing water content in concrete (maintaining the original water/cement ratio) based on the variation in ambient and the concrete temperature.

This procedure optimizes cement consumption, generating both economic benefits associated with lower production costs and environmental benefits through the indirect reduction of $\mathrm{CO}_{2}$ emissions. It also leads to social benefits by providing added value to the end user of these concretes.

The preceding is also useful as a way of mitigating the $\mathrm{CO}_{2}$ emissions generated by the ready mix concrete industry (20), for cement accounts for from 74 to $85 \%$ of the total emissions attributable to concrete production (21).

The present article aims to describe the methodology developed and the results obtained when it was used on an industrial scale in a number of plants producing ready mix concrete.

\section{INITIAL APPROACH}

\subsection{Theoretical fundamentals and general considerations}

The methodology proposed to optimize cement consumption in concrete in the summertime is based on theoretical fundamentals respecting the dependence of concrete strength on ambient and early age concrete temperature and subsequently on the heat of hydration and heat transfer to or its absorption from the atmosphere. This approach to industrial scale decisionmaking is based in principle on the initial and maximum 
dada en un principio en base a la temperatura inicial y máxima que pueda alcanzar un hormigón, en función de las temperaturas ambientales de un día dado y de la hora en que sea fabricado.

Los detalles analíticos del planteamiento numérico de la metodología desarrollada se muestran en (2-22). Asimismo, cabe mencionar también que este planteamiento fue la primera versión de la metodología desarrollada, ya que, como se mostrará posteriormente, la misma fue evolucionando y mejorando progresivamente.

Una condicionante importante para el desarrollo de cualquier medida de actuación es que la misma debe ser programable e implementable de manera sencilla a nivel industrial, en este caso, sobre las plantas de producción de hormigón preparado.

Por lo anterior, fue necesario verificar y validar la viabilidad del planteamiento metodológico desarrollado sobre hormigones elaborados en laboratorio, a diferentes horas del día dentro de un ciclo de condiciones térmicas variables (temperatura y humedad relativa) y aplicando al mismo tiempo una política escalonada de sobredosificación de cemento (2).

A continuación se presenta en la Figura 1 una versión general del diagrama de flujo para el planteamiento metodológico inicial desarrollado para optimizar la sobredosificación de cemento en el hormigón en función de las condiciones térmicas ambientales. Esta metodología podrá ser programada e integrada al sistema informático de producción de cada planta de hormigón.

La temperatura de la masa fresca del hormigón se determina en base a la teoría de mezclas en función de la temperatura de sus componentes. La del cemento y agua a través de las mediciones tradicionales y la de los áridos a través de las estimaciones hechas mediante el ensayo de inercia térmica (2) y contrastada por mediciones en los acopios. Asimismo se puede conocer el calor específico de los constituyentes y la capacidad calorífica del hormigón.

La temperatura ambiente en el tiempo se moldea matemáticamente a través de la utilización de funciones bilineales, biparabólicas y senoidales. Para eso se establece como datos de partida las temperaturas ambientes máxima $\left(T_{\max }\right)$ y mínima $\left(T_{\min }\right)$ diarias así como las horas del día en que ocurren, $h_{\max }$ y $h_{\min }$, respectivamente. Las funciones senoidales presentaron una mejor correlación con las tendencias térmicas cíclicas presentadas a lo largo del día resultando en una mayor precisión (23). temperatures that can be reached in concrete, depending on the ambient temperature on the day and time the concrete is made.

The analytical details of the numerical approach to the method are given in (2-22). This approach, the first version of the methodology developed, was subsequently modified and improved, as discussed below.

One important requirement to be met by any practical measure is programmability and ease of implementation on an industrial scale, in this case in ready mix concrete plants.

The methodology had, therefore, to be verified and validated with laboratory-prepared concrete at different times of day in a thermal cycle in which the temperature and relative humidity were varied, while progressively increasing the overdoses of cement (2).

Figure 1 shows the flowchart for the initial methodology developed to optimize cement overdosing in concrete for any given ambient temperature. This methodology can be programmed and entered into concrete plants' computerized production system.

In this approach, the temperature of the fresh concrete was found pursuant to theory of mixtures based on the temperature of the components. Traditional methods were used to measure cement and water temperature, while the temperature of the aggregate was found with thermal inertia test estimates (2), subsequently compared to measurements taken in the stored aggregate. The methodology can also be used to find the specific heat of the constituents and the concrete heat capacity.

The ambient temperature was mathematically fitted to bilinear, biparabolic and sigmoid functions. The starting data established for this purpose were the daily maximum ( $\left.T_{\max }\right)$ and minimum $\left(T_{\min }\right)$ ambient temperatures and the respective times of day $\left(h_{\max }\right.$ and $\left.h_{\text {min }}\right)$. The sigmoid functions were found to be more closely correlated to the daily thermal cycles, yielding greater precision (23). 


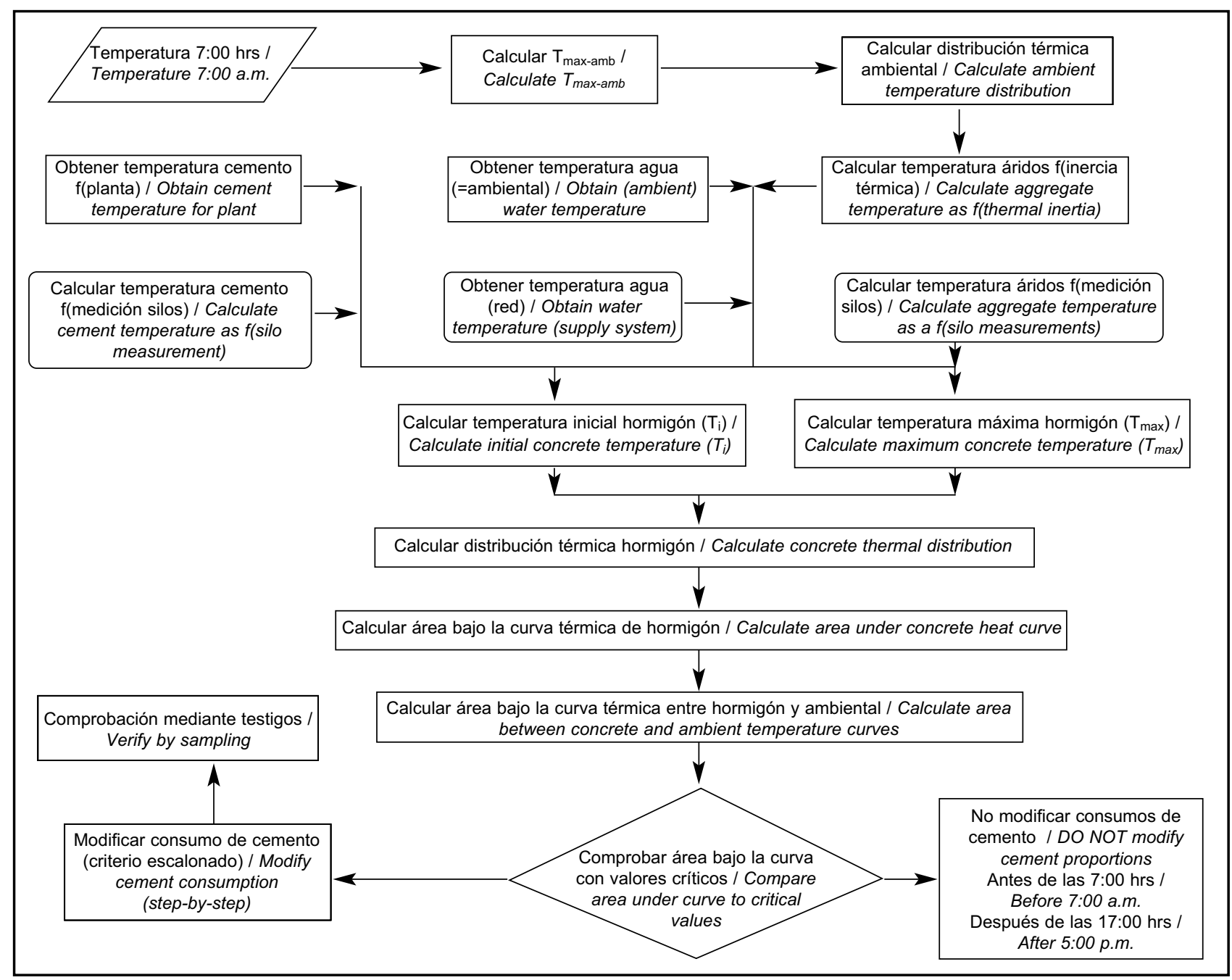

Figura 1. Diagrama de flujo del planteamiento metodológico inicial.

Figure 1. Flow chart for initial methodology.

En este caso, con el objeto de poder predecir con cierta certeza estadística (cerca del 95\% de intervalo de confianza) los valores de $T_{\max }$ y $T_{\min }$ para cada día en función de la temperatura que se tenga a las 7:00 de la mañana, se hizo un análisis estadístico de todos los días de los meses de verano (junio, julio y agosto) de los últimos 10 años (1997-2006), con los datos facilitados por el Servicio Meteorológico de Cataluña (24).

Este análisis estadístico se formuló en base a las distribuciones de frecuencia de las temperaturas, las cuales se ajustaban a una morfología "gaussiana" y por lo tanto pueden ser modeladas estadísticamente por medio de una función de probabilidad del tipo t-Student, la cual funciona bien en los casos en que el tamaño de la muestra analizada es pequeño en comparación con el tamaño de la población.
Here, to be able to predict the $T_{\max }$ and $T_{\min }$ values for each day based on the temperature recorded at 7:00 a.m. with some degree of statistical certainty (confidence interval of nearly 95\%), a statistical analysis was run for all the days in the months of June, July and August over the last 10 years (1997-2006) using data furnished by the Meteorological Service of Catalonia (24).

This statistical analysis drew from temperature frequencies which, exhibiting normal distributions, could be statistically modelled with a Student's t-type probability distribution, a tool that yields good results when the sample is small compared to the size of the population. 


\subsection{Verificación experimental en laboratorio}

Con el objeto de verificar el buen funcionamiento del planteamiento metodológico desarrollado, se realizó una campaña experimental sobre hormigones fabricados en laboratorio a diferentes horas del día dentro de un ciclo térmico variable y aplicando una política escalonada de sobredosificación de cemento (consumos variables).

En base a este planteamiento metodológico (para la optimización de las sobredosificaciones de cemento en el hormigón en verano), fueron calculados las sobredosificaciones de cemento para cada intervalo horario, considerando las variaciones diarias de la temperatura ambiente.

El ciclo térmico utilizado en la campaña experimental corresponde a las condiciones de verano características para el área metropolitana de Barcelona (1), en el cual fueron hechas seis amasadas a diferentes horas del día, obteniendo la trabajabilidad y la resistencia a compresión a 7 y 28 días.

La Tabla 1 muestra la propuesta de sobredosificaciones de cemento para cada intervalo horario del día, así como la hora en que se fabricó cada hormigón; los valores mostrados en dicha tabla son valores redondeados.

\subsection{Laboratory verification}

An experimental campaign was conducted on laboratory concrete prepared at different times of day in the variable thermal cycle using increasing overdoses of cement to verify the effectiveness of the methodological approach developed.

Using this methodology for optimizing cement overdosing in concrete made in the summertime, the proportion of cement was calculated for each hourly interval based on the daily variations in ambient temperature.

The thermal cycle used in the experimental campaign simulated the summertime conditions characteristic of the Barcelona metropolitan area (1). Six batches were prepared at different times of day, and workability and 7- and 28-day strength were found for each.

Table 1 gives the proposed cement overdoses for each time interval and the time that each concrete was made. The values given are rounded.

Tabla 1 / Table 1

Propuesta de sobredosificaciones de cemento en el hormigón para cada intervalo horario. Proposed overdoses of cement in concrete for each time interval.

\begin{tabular}{|c|c|}
\hline Intervalo / Interval (hrs) & Sobredosificación cemento / Cement overdose $\mathbf{( k g} / \mathbf{m}^{\mathbf{3}}$ ) \\
\hline$<07: 00$ & 0 \\
\hline $07: 00-09: 00$ & 5 \\
\hline $09: 00-11: 00$ & 10 \\
\hline $11: 00-14: 00$ & 15 \\
\hline $14: 00-16: 00$ & 10 \\
\hline $16: 00-17: 00$ & 5 \\
\hline$>17: 00$ & 0 \\
\hline
\end{tabular}

En este caso las relaciones agua/cemento se mantienen constantes, incrementando en la misma proporción el contenido de agua y de cemento. Es importante mencionar que esta tabla debe ser ajustada para cada planta de hormigón, de acuerdo con las variaciones de la temperatura local en función de su ubicación geográfica; en este caso, dicha tabla corresponde a las condiciones climatológicas del área metropolitana de Barcelona.

\subsubsection{Resultados térmicos}

Las Figuras 2 ( $a$, b c c y d) muestran los resultados térmicos obtenidos: temperatura ambiental, temperatura de los áridos, temperatura inicial del hormigón y la evolución de la temperatura del hormigón (bajo condiciones adiabáticas y no-adiabáticas, respectivamente. Para todas las gráficas, se incluyen las curvas teóricas y las curvas reales, teniendo en general buenos ajustes.
In this case the water/cement ratios were kept constant, increasing water and cement in the same proportion. The above table, formulated, as mentioned above, for the climate in the metropolitan area of Barcelona, would have to be adjusted to the conditions prevailing at each concrete plant in keeping with local temperature variations.

\subsubsection{Thermal findings}

The thermal findings are shown in Figure $2(a, b, c$ and d): ambient temperature, aggregate temperature, initial concrete temperature and variation in concrete temperature over time (under adiabatic and nonadiabatic conditions). The theoretical and actual curves shown in all the graphs denote the generally good fits. 


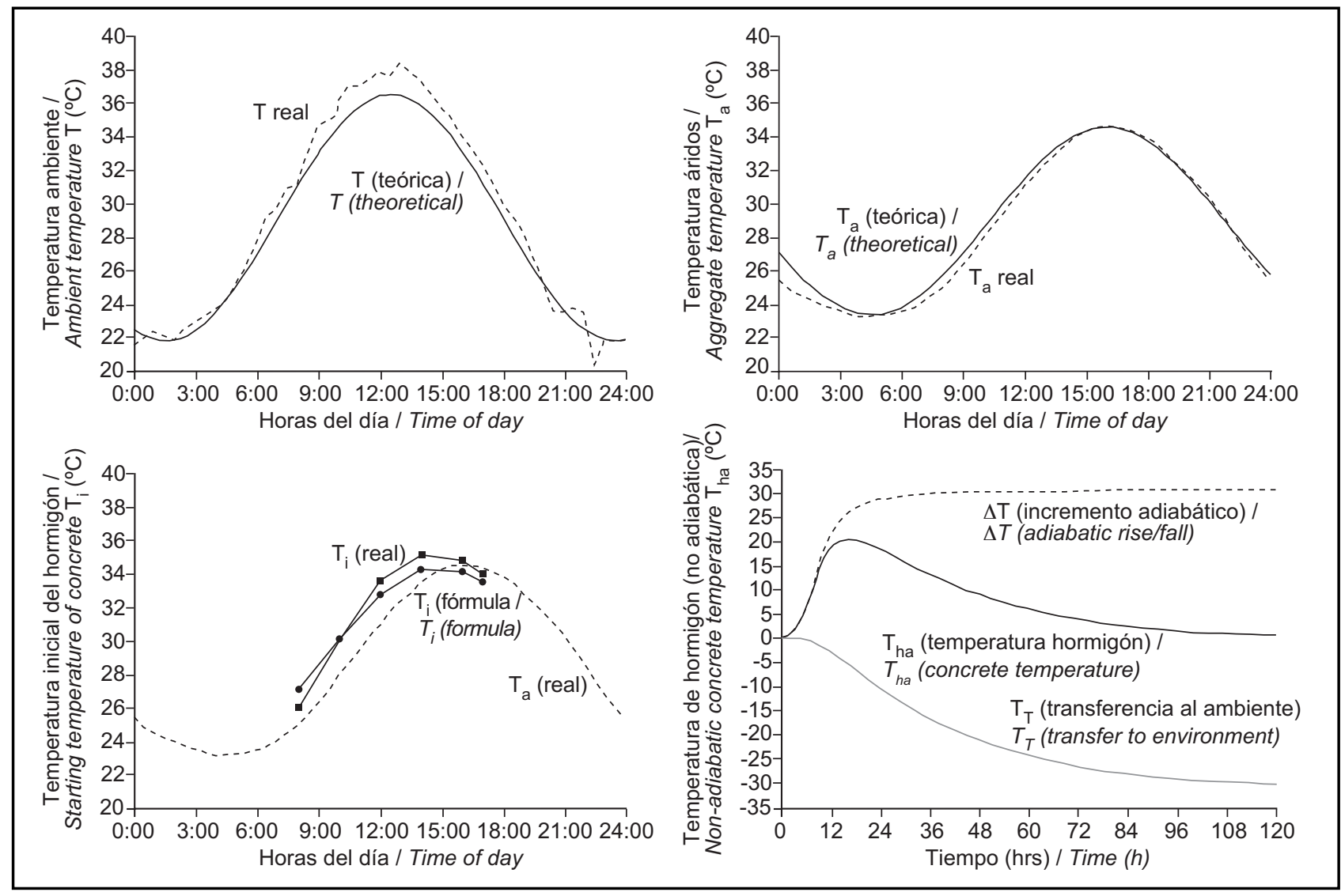

Figura 2. Resultados térmicos (simulación numérica vs real). (a) Temperatura ambiente. (b) Temperatura de los áridos.

(c) Temperatura inicial hormigón, (d) Temperatura hormigón condiciones no adiabáticas.

Figure 2. Thermal findings (numerical simulation vs real data). (a) ambient temperature. (b) aggregate temperature,

(c) initial concrete temperature. (d) concrete temperature under non-adiabatic conditions.

Para cada amasada, también se registró la temperatura de la masa fresca del hormigón, con el objeto de comparar los perfiles térmicos registrados con las predicciones hechas en base al planteamiento metodológico desarrollado para la política de toma de decisiones. Los perfiles térmicos de predicción y reales de la masa fresca del hormigón se
The temperature of each batch of fresh concrete was also recorded to compare the thermal profiles to the predictions made pursuant to the decision-making methodology developed. The theoretical and real

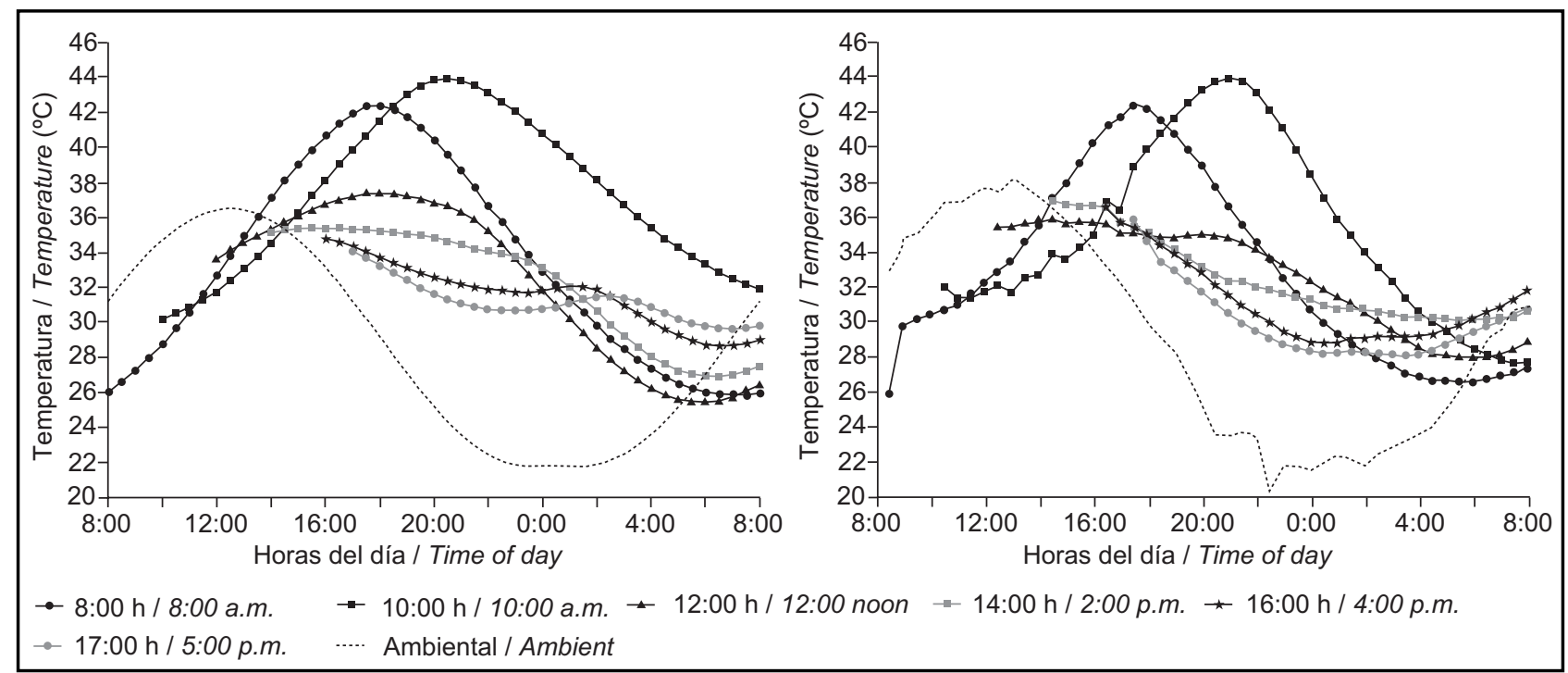

Figura 3. Perfiles térmicos de los hormigones. (a) Perfiles calculados. (b) Perfiles medidos realmente. Figure 3. Thermal profiles for concrete. (a) Profiles calculated. (b) Profiles measured. 
muestran en las Figuras 3 ( $a$ y $b$ ), respectivamente, en las cuales también puede verse en general un buen ajuste entre los valores registrados y los calculados.

\subsubsection{Resultados mecánicos}

Los resultados de resistencia a compresión fueron obtenidos en base a la media de los valores obtenidos en todas las probetas de hormigón para cada amasada.

En las Tablas 2 y 3 se presentan los valores de la media de resistencia a compresión a 7 y 28 días, así como las sobredosificaciones de cemento calculados para cada hora de fabricación y los valores de desviación estándar y coeficientes de variación obtenidos, con el objeto de medir la dispersión global de todo el día. Lo anterior considerando que el objetivo era obtener, en teoría, la misma resistencia en cada hora de fabricación variando los consumos de cemento en función de las condiciones climáticas. thermal profiles for fresh concrete plotted in Figures 3 (a and $b$ ) likewise show a generally good fit.

\subsubsection{Mechanical findings}

The compressive strength was found as the mean of the values recorded for all the concrete specimens from each batch.

Tables 2 and 3 give the 7- and 28-day mean compressive strengths, the overdose of cement calculated for each preparation time and the standard deviations and coefficients of variation obtained to measure overall dispersion throughout the day. This was relevant to the ultimate aim of this study, i.e., to produce concrete with the same strength at any time of day by varying the cement proportion with weather conditions.

Tabla 2 / Table 2

Resultados de resistencia a compresión a 7 días.

7-day compressive strength.

\begin{tabular}{|c|c|c|c|c|c|c|c|}
\hline \multicolumn{6}{|c|}{ Resistencia a compresión, 7 días / 7-day mean compressive strength } \\
\hline \multirow{2}{*}{ Parámetro estadístico / Statistical parameter } & \multicolumn{6}{|c|}{ Hora de fabricación / Time of day } \\
\cline { 2 - 10 } & $08: 00$ & $10: 00$ & $12: 00$ & $14: 00$ & $16: 00$ & $17: 00$ & Global / Overall \\
\hline Sobreconsumo / Overdose (kg/m) & 5 & 10 & 15 & 10 & 5 & 0 & Variable / Variable \\
\hline Media / Mean (MPa) & 31.7 & 34.0 & 33.5 & 34.8 & 35.9 & 34.8 & 34.1 \\
\hline Desviación estándar / Standard deviation (MPa) & 0.141 & 1.485 & 0.636 & 0.990 & 0.636 & 0.212 & 1.427 \\
\hline C.V. / C.V. (\%) & 0.4 & 4.4 & 1.9 & 2.8 & 1.8 & 0.6 & 4.2 \\
\hline
\end{tabular}

Tabla 3 / Table 3

Resultados de resistencia a compresión a 28 días. 28-day compressive strength.

\begin{tabular}{|c|c|c|c|c|c|c|c|}
\hline \multicolumn{7}{|c|}{ Resistencia a compresión, 28 días / 28-day mean compressive strength } \\
\hline \multirow{2}{*}{ Parámetro estadístico / Statistical parameter } & \multicolumn{6}{|c|}{ Hora de fabricación / Time of day } \\
\cline { 2 - 9 } & $08: 00$ & $10: 00$ & $12: 00$ & $14: 00$ & $16: 00$ & $17: 00$ & Global / Overall \\
\hline Sobreconsumo /Overdose (kg/m $\mathbf{3})$ & 5 & 10 & 15 & 10 & 5 & 0 & Variable / Variable \\
\hline Media /Mean (MPa) & 44.4 & 46.5 & 47.3 & 48.1 & 49.8 & 46.6 & 47.1 \\
\hline Desviación estándar / Standard deviation (MPa) & 0.141 & 0.000 & 1.273 & 0.990 & 0.283 & 1.838 & 1.802 \\
\hline C.V. / C.V. (\%) & 0.3 & 0.0 & 2.7 & 2.1 & 0.6 & 3.9 & 3.8 \\
\hline
\end{tabular}

Los resultados mostrados tienen una dispersión interna menor al 4\% (coeficiente de variación), la cual responde al comportamiento esperado, ya que las sobredosificaciones de cemento fueron optimizados dependiendo de la temperatura ambiental y del propio hormigón, con el objeto de mantener una misma resistencia a lo largo del día. Esta pequeña variación podría responder a la dispersión propia del método experimental, ya que las relaciones agua/cemento eran constantes para todas las horas de fabricación.
The internal dispersion in these results was less than $4 \%$ (coefficient of variation), as expected, for the cement overdoses were optimized depending on the ambient and concrete temperature to produce concrete of uniform strength throughout the day. This minor variation may have been due to the experimental method itself, since the water/cement ratios were constant throughout. 


\subsection{Formulación para implementarse a nivel industrial}

En base al planteamiento presentado anteriormente, es posible determinar el perfil térmico que tendrá un hormigón bajo diferentes circunstancias (dosificación, contenido y tipo de cemento, condiciones ambientales, etc.). Una vez conocidas las temperaturas inicial $\left(T_{i}\right)$ y máxima ( $\left.T_{\max }\right)$ del hormigón, así como la distribución térmica ambiental a lo largo del día en función de las condiciones ambientales específicas, es posible calcular el área bajo la curva térmica entre el hormigón y la temperatura ambiental; y de esta forma, formular una tabla de sobredosificaciones de cemento en el hormigón.

Los datos de partida para tal formulación fueron una combinación entre el planteamiento teórico-térmico desarrollado inicialmente y las experiencias aprendidas a lo largo de los trabajos realizados en (2). En este sentido se analizaron numéricamente todas las posibles combinaciones en función de la temperatura ambiental y de la hora del día.

Asimismo, los intervalos de temperatura ambiental fueron ajustados de tal forma que los consumos de cemento fueran múltiplos de $5 \mathrm{~kg} / \mathrm{m}^{3}$, con el objeto de facilitar la implementación manual en la producción.

Dicha formulación tiene como consideraciones básicas las siguientes:

1. Valores de temperatura ambiental máxima obtenidos mediante distribución estadística (t-student) de los meses de junio, julio y agosto del período de años comprendido entre 1997 y 2006 (10 años).

2. Valores de temperatura obtenidos del Observatorio Fabra de Barcelona (clima mediterráneo) (24).

3. Temperaturas mayores a $30^{\circ} \mathrm{C}$ a las $7: 00$ horas solo se registraron en 4 días dentro del período de 10 años.

4. El intervalo de 27 a $30^{\circ} \mathrm{C}$ a las 7:00 hrs es el que corresponde con el estudiado experimentalmente.

Estas sobredosificaciones de cemento están calculadas para el cemento CEM I 42,5 R, tomando como referencia un hormigón de $25 \mathrm{MPa}$ con relación $\mathrm{A} / \mathrm{C}=0,56$.

\section{OTRAS ALTERNATIVAS ESTUDIADAS}

En función de los buenos resultados obtenidos a través de la herramienta para la toma de decisiones, fue propuesto el análisis de algunas otras alternativas, con el objeto de investigar si eran más adecuadas desde el punto de vista industrial, con el objeto de hacer que la metodología fuese aún más eficaz (25).

\subsection{Scheme for industrial implementation}

The approach under discussion proved to be able to reliably determine the thermal profile of a concrete under different circumstances (cement proportion, content and type, environmental conditions and so on). Knowing the starting $\left(T_{i}\right)$ and maximum $\left(T_{\max }\right)$ concrete temperatures, as well as the distribution of the ambient temperature during the day depending on specific environmental conditions, the area under the concrete temperature - ambient temperature curve can be calculated and used to formulate a cement overdosing table.

In the present case, the starting data for the table were a combination of the theoretical-thermal approach initially developed and the experience acquired during the study (2). In this regard, all the possible numerical combinations were analyzed as a function of ambient temperature and time of day.

The ambient temperature intervals were also adjusted to be able to use cement proportions that were multiples of $5 \mathrm{~kg} / \mathrm{m}^{3}$ to facilitate manual production.

The basic considerations for formulating the table were:

1. The maximum ambient temperature values were obtained from the statistical distribution (Student-t) for the months of June, July and August over 10 years, 1997-2006.

2. The temperatures used were furnished by the Fabra Observatory at Barcelona (Mediterranean climate) (24).

3. Temperatures of over $30^{\circ} \mathrm{C}$ at 7:00 a.m. were only recorded on four days in that 10-year period.

4. In the experimental study, the 7:00 a.m. temperature values used ranged from 27 to $30^{\circ} \mathrm{C}$.

The respective cement overdoses were calculated for cement CEM I $42.5 R$, taken as a 25-MPa reference cement with a $w / c$ ratio of 0.56 .

\section{OTHER ALTERNATIVES STUDIED}

In light of the good results obtained with the decisionmaking tool, and with a view to enhancing its effectiveness, other working conditions were introduced and new parameters studied to explore their suitability to the industrial context (25). 
Inicialmente, fueron instalados sistemas de medición automática de la temperatura ambiental (del aire), lo que desvinculaba la toma de decisiones a juicios humanos $y$, por lo tanto, a posibles errores.

Otro avance, en este sentido, fue la posibilidad de ampliar la cantidad de registros de temperaturas semi-horarias de todos los días de los meses de verano (junio, julio y agosto) de más años, acrecentando el tamaño de la muestra y reduciendo estadísticamente las diferencias entre las temperaturas estimadas (predicciones) y las registradas realmente.

Por otro lado, se planteó estudiar algunas otras variables o parámetros de carácter ambiental que pudieran incidir en el comportamiento del hormigón desde el punto de vista de trabajabilidad y resistencia, y que mejoraran y complementaran la metodología desarrollada.

\subsection{Evaluación de la influencia de la humedad relativa}

En la implementación práctica en las centrales de hormigonado en el primer año de funcionamiento de la metodología, se observaron algunas desviaciones en cuanto a las previsiones de las sobredosificaciones de cemento en plantas con acopios de áridos no cubiertos, en los días en los cuales había llovido en horas previas a la fabricación del hormigón. Lo anterior llevó a pensar en realizar alguna corrección complementaria al planteamiento inicial para tener en cuenta esta circunstancia, en especial haciendo énfasis en la humedad relativa del aire como elemento complementario de control.

El objetivo de este planteamiento era analizar la idoneidad de utilizar la humedad relativa del aire como un segundo parámetro de control en la sobredosificación de cemento en el hormigón, y su posible aplicación en situaciones reales en plantas de producción de hormigón preparado.

La humedad relativa (HR), como es bien sabido, presenta un comportamiento inversamente proporcional a la temperatura, es decir, cuando la temperatura baja, la humedad relativa sube y cuando la temperatura sube, la humedad relativa decrece, siendo este último caso el más perjudicial para el hormigón. En este sentido, se llevó a cabo una revisión bibliográfica sobre el estado del conocimiento que engloba las bases físicas de la humedad relativa y las fórmulas analíticas que la relacionan con la temperatura.

Con posterioridad, se realizó un análisis con base en las condiciones ambientales prevalecientes en el ámbito geográfico de Cataluña, llegándose a la conclusión de que tanto la temperatura como la humedad relativa son parámetros de igual confiabilidad para el control de las variaciones climáticas en la dosificación del hormigón. Sin embargo, un parámetro no complementa al otro, pero sí, resultan equivalentes.
Automatic ambient (air) temperature measuring systems were initially installed to remove the human element and concomitant risk of error.

Another improvement consisted in expanding the number of temperature records by using half-hourly temperatures records for all the days of the months of June, July and August across a wider range of years, thereby increasing the sample size and narrowing the statistical differences between the estimated (predictions) and actual temperature values.

Other environmental variables and parameters were studied that might impact concrete workability and strength and improve and supplement the methodology.

\subsection{Evaluation of the effect of relative humidity}

In the first year of implementation, certain deviations were observed with respect to cement overdoses in plants where uncovered aggregate was exposed to rain a few hours before the concrete was made. The result was a new line of study in pursuit of a correction to the initial approach that would take this circumstance into consideration, targeting relative humidity as a supplementary source of control.

The aim was to analyze the use of relative humidity as a second control parameter in cement overdosing in concrete and its possible application in ready mix concrete plants.

Relative humidity $(\mathrm{RH})$ is known to be inversely proportional to temperature: i.e., when the temperature declines, the relative humidity rises and vice-versa. High temperature and low relative humidity are the conditions that are least favourable to concrete strength development. The literature was reviewed to determine the state of the art of the physics of relative humidity and the analytical formulas relating it to temperature.

An analysis was subsequently performed on the basis of the environmental conditions prevailing in Catalonia, Spain. The conclusion initially drawn was that temperature and relative humidity are equally reliable parameters for monitoring concrete proportioning as a function of climatic change. Nonetheless, the two parameters were not observed to be complementary, although did prove to be equivalent. 
Con el objeto de ilustrar la correspondencia en cuanto a comportamiento entre la temperatura y la humedad relativa y el efecto de la precipitación pluvial sobre estas dos variables, se presentan a continuación las Figuras 4 y 5 , donde se muestra la evolución de la temperatura y humedad relativa a lo largo de tres días de verano $(26,27$ y 28 de agosto de 2005) de la estación meteorológica Fabra de Barcelona (24) y la ocurrencia de precipitaciones pluviales en algunos momentos de esos días, respectivamente.
Figures 4 and 5 below respectively show the variations in temperature versus relative humidity on three summer days (26, 27 and 28 August 2005) at the Fabra, Barcelona weather station (24) and rainfall on those days. These data illustrate the inverse relationship between temperature and relative humidity and the effect of precipitation on both.

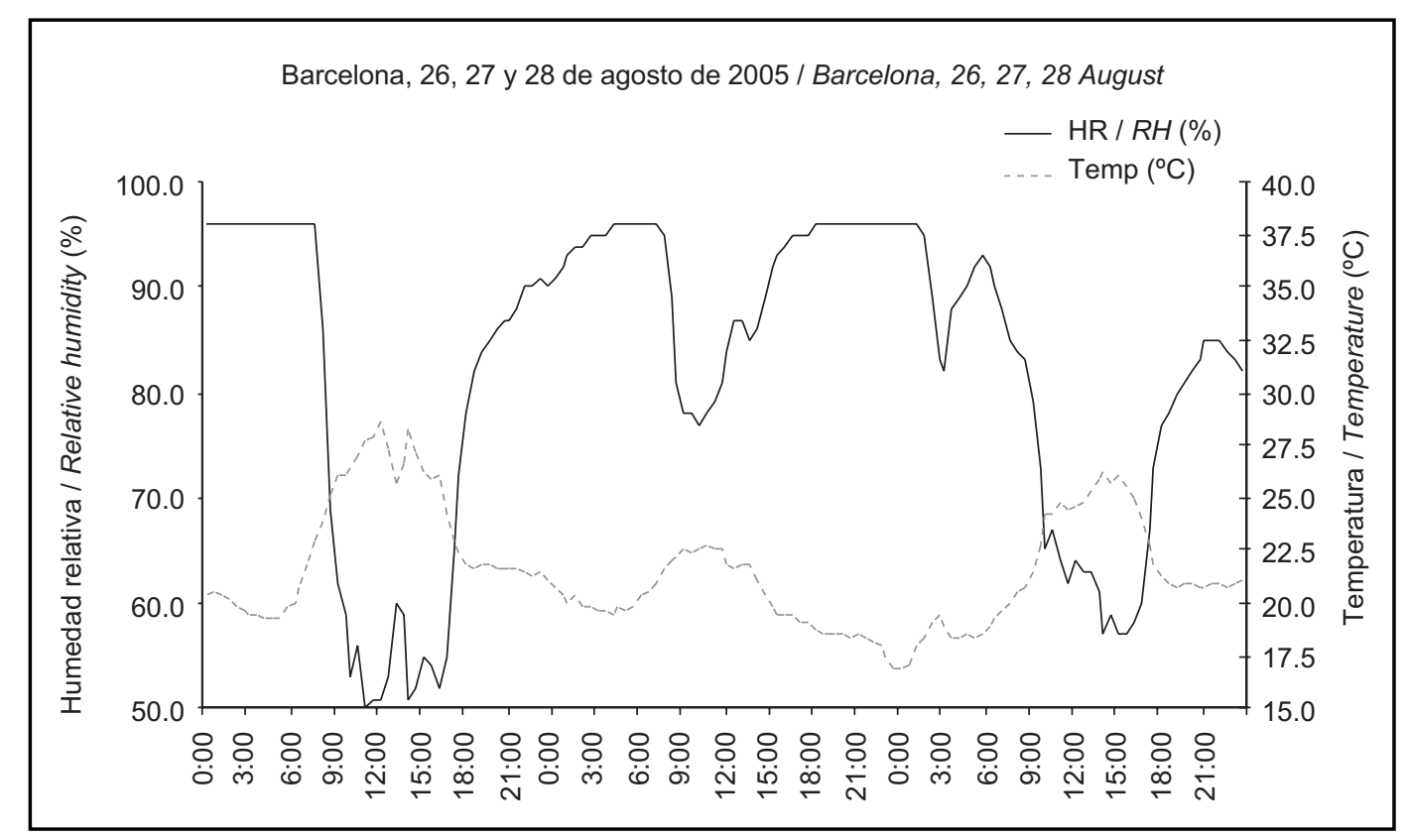

Figura 4. Temperatura vs humedad relativa en tres días de verano en Barcelona. Figure 4. Temperature vs relative humidity on three days in Barcelona.

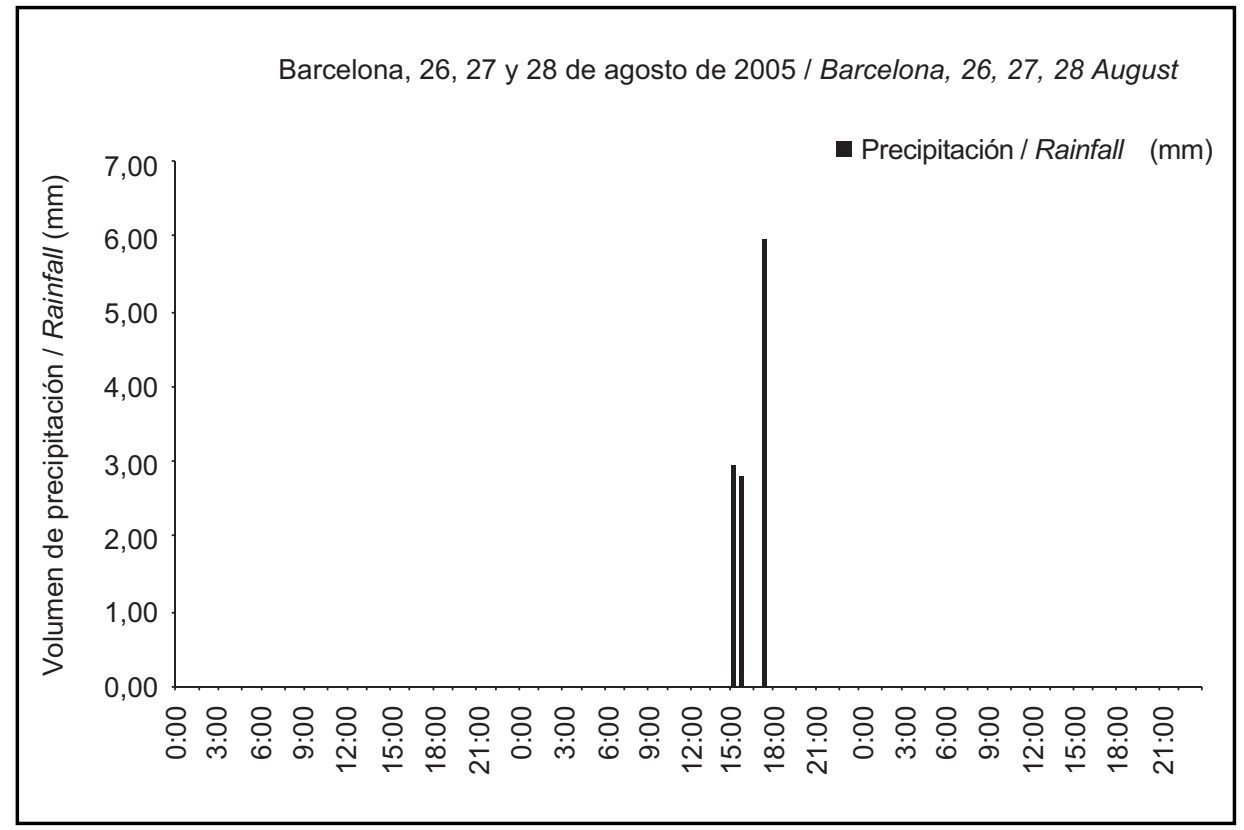

Figura 5. Precipitación pluvial en tres días de verano en Barcelona. Figure 5. Rainfall on three days in Barcelona. 
En las figuras anteriores puede apreciarse que los efectos de la precipitación (tanto en la temperatura como en la humedad relativa) empiezan a observarse desde las primeras horas de la mañana antes de producirse, lo cual puede ser reflejo de una variación de presión que muestra que se avecinan Iluvias.

Ahora bien, el parámetro temperatura es más sensible que el parámetro humedad, lo cual en cierta forma permite concluir que la humedad relativa del aire no es un parámetro adecuado de control para optimizar la sobredosificación de cemento en el hormigón en verano, por lo cual se descartó esta variable.

\subsection{Evaluación de la influencia de la presión atmosférica}

El objetivo de este segundo planteamiento era analizar la idoneidad de utilizar la presión atmosférica del aire como otro parámetro de control en la sobredosificación de cemento en el hormigón, y su posible aplicación en situaciones reales en plantas de producción de hormigón preparado.

La presión atmosférica es uno de los elementos del tiempo menos notable, sin embargo, tiene gran importancia en las variaciones diarias del tiempo, ya que genera los vientos, que a su vez producen variaciones de la temperatura o de la humedad relativa o de la precipitación.

De forma análoga a como se ha procedido con anterioridad, en base a los registros facilitados por el Servicio Meteorológico de Cataluña (24) relativos a la presión atmosférica, se analizaron diversas situaciones singulares producidas en varios días correspondientes a los meses de verano en dos estaciones meteorológicas.

En este sentido se analizaron los comportamientos ambientales de algunos días dentro de los meses de verano con y sin precipitaciones, con el objeto de encontrar una posible correlación entre la temperatura y la presión atmosférica, para poder predecir las variaciones de temperatura cuando se presenten precipitaciones pluviales. Los resultados obtenidos de estos análisis indican que en general hay períodos en que la tendencia de la presión atmosférica se corresponde muy bien con la tendencia de la temperatura ambiental en períodos largos de tiempo (p.ej. un mes), sin embargo, los cambios en la presión atmosférica nada dicen con respecto a la presencia de precipitaciones en períodos cortos de tiempo (p. ej. un día).

Se muestra a continuación en la Figura 6, la evolución de la temperatura y de la presión atmosférica a lo largo de un día de verano (16 de junio de 2006) (24), en el cual hubo precipitación pluvial.
According to these figures, rain affects both temperature and relative humidity from early in the morning before it actually begins to rain, perhaps reflecting variations in atmospheric pressure indicative of the advent of rain.

Inasmuch as temperature proved to be a more sensitive parameter than humidity for monitoring cement overdosing in concrete in the summertime, the use of $\mathrm{RH}$ for these and intents and purposes was ruled out.

\subsection{Evaluation of the effect of atmospheric pressure}

The aim of this second approach was to analyze the use of atmospheric pressure as a control parameter in cement overdosing in concrete and its possible application in ready mix concrete plants.

While atmospheric pressure is one of the least perceptible elements of the weather, it has a significant impact on daily variations, for it generates wind which in turn causes variations in temperature, relative humidity and precipitation.

Proceeding in much the same way as above, the atmospheric pressure records furnished by two Catalonia Meteorological Service (24) weather stations were used to analyze specific situations on a number of summer days.

Days both with and without precipitation were chosen for this purpose, to detect possible correlations between temperature and atmospheric pressure from which to predict temperature variations in the event of rain. The findings showed that while as a rule trends in atmospheric pressure matched ambient temperature trends over fairly long periods (such as one month), changes in atmospheric pressure was ineffective for predicting the presence of rainfall in short periods of time (such as one day).

Figure 6 below plots the variations in temperature and atmospheric pressure on a rainy summer day, 16 June 2006 (24). 


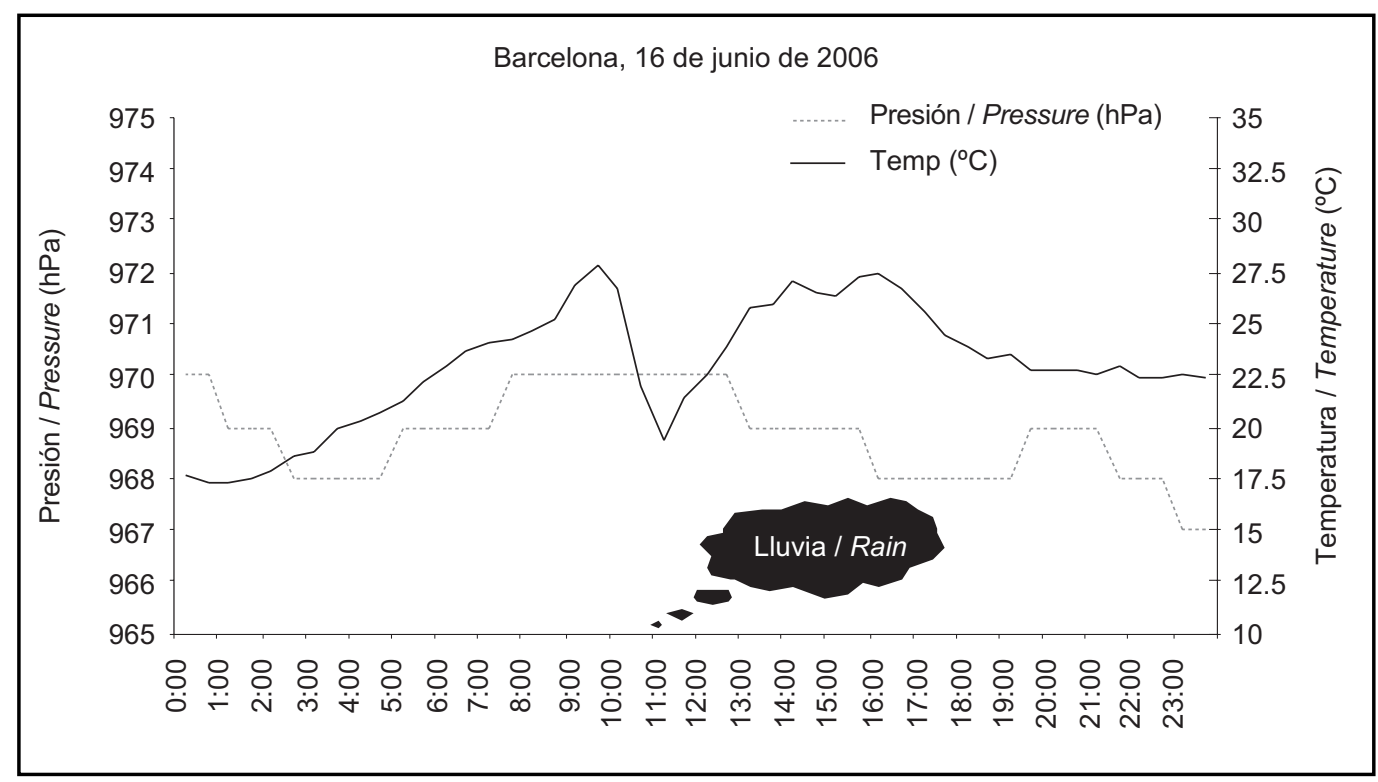

Figura 6. Temperatura vs presión atmosférica en un día de verano con precipitación pluvial. Figure 6. Temperature vs atmospheric pressure on a rainy summer day.

Puede verse en la figura anterior que la variación de la presión atmosférica no fue afectada por la ocurrencia de precipitación pluvial en esas horas ni por la variación de la temperatura (descenso). Lo anterior permitió concluir que la presión atmosférica no es un indicador alternativo como parámetro de control de la sobredosificación de cemento en el hormigón, con relación al parámetro de temperatura ambiental, utilizado hasta la fecha.

\subsection{Toma de decisiones basada en incrementos y decrementos de temperatura}

Este tercer planteamiento tiene como objetivo tratar de desarrollar un parámetro de control estadístico de la sobredosificación de cemento en el hormigón, basado en los incrementos o pérdidas de temperatura ambiental, los cuales pueden correlacionarse directamente con la presencia de precipitaciones, sin la necesidad de instalación de equipo industrial especializado.

En este sentido, para tomar decisiones en base a los incrementos y/o decrementos de temperatura ambiental producidos por la ocurrencia de lluvia, fue necesario desarrollar un parámetro que considerase la velocidad de subida y bajada de temperatura, tomando como referencia el ángulo que forma la horizontal con las curvas térmicas (reales y de predicción) de subida o bajada.

No obstante, después de haber llevado a cabo un amplio estudio estadístico, analizando varios registros históricos de días de verano con presencia de precipitaciones pluviales, se llegó a la conclusión de que la aplicación de un parámetro de control para la sobredosificación de
The figure shows that the atmospheric pressure was not affected either by rainfall or by the (downward) variation in temperature. The conclusion drawn was that this parameter is not a viable alternative to temperature for monitoring cement overdosing in concrete.

\subsection{Decision-making based on rises and declines in temperature}

This third approach aimed to develop a statistical parameter for monitoring cement overdosing in concrete based on the rise or decline in ambient temperature, which can be directly correlated to the presence of precipitation with no need for specialized industrial facilities.

The use of rainfall-induced rises or declines in ambient temperature as the basis for decision-making called for developing a parameter that would accommodate temperature rises and falls, taking the slope of the (real and predicted) upward and downward thermal curves as a reference.

Nonetheless, a statistical analysis of a number of historical records for rainy summer days led to the conclusion that the use of a parameter based on the slope of ambient temperature curves to determine the effect of precipitation on the rise or fall of ambient 
cemento en el hormigón, en función de la pendiente de las curvas térmicas ambientales para determinar la influencia de las precipitaciones en los incrementos $\mathrm{y} / \mathrm{o}$ decrementos de la temperatura ambiental, tornan compleja su aplicación práctica, ya que los resultados arrojados en dicho estudio no muestran tendencias muy claras.

\subsection{Consideraciones finales}

Las precipitaciones cambian el comportamiento térmico del árido con respecto a la temperatura ambiental, es decir, después de una precipitación, el árido presenta una temperatura más baja que la temperatura del aire debido a la pérdida de calor por evaporación. Esto hace que después de la lluvia la sobredosificación de cemento puede ser reducida, lo cual ha sido la razón de ser de este estudio.

Frente a las diversas variables estudiadas para un avance en la metodología, y relacionando la facilidad de implementación al valor aportado por cada una de ellas, se decidió mantener la toma de decisiones basada únicamente en la temperatura ambiental, como parámetro de control para optimizar la sobredosificación de cemento en el hormigón en verano.

En este sentido, se implementó un sistema automatizado de medición en tiempo real de la temperatura ambiental, y, de esta forma, no es ya necesario correlacionar la sobredosificación de cemento con los segmentos horarios del día. De este modo, la optimización de la sobredosificación de cemento en el hormigón se hace de manera directa, en función de la temperatura ambiental en el momento de la amasada.

\section{RESULTADOS OBTENIDOS}

Con el objetivo de verificar los resultados obtenidos, fue realizado un análisis estadístico sobre los valores de de resistencia a compresión de probetas cilíndricas del control de calidad de varias plantas de producción de hormigón preparado en Cataluña, una vez implementada la metodología.

Los parámetros determinados a partir de los resultados a compresión del hormigón, fueron los siguientes: número de muestras, resistencia media, resistencia característica estimada, desviación estándar, coeficiente de variación, sobredosificación de cemento, dosificación total de cemento, ahorro relativo de cemento y asentamiento. Cabe mencionar, que en el presente artículo se presentarán solamente los resultados correspondientes a la resistencia media a compresión del hormigón. temperature and thereby monitor cement overdosing in concrete was highly complex in practice, for no clear trends could be identified.

\subsection{Final remarks}

Precipitation changes the thermal behaviour of aggregate with respect to the ambient temperature: i.e., when it rains, the temperature of the aggregate declines to below the ambient temperature due to evaporation. Hence, after a rain, cement overdosing can be reduced. That finding fulfilled the ultimate objective of this study.

After exploring a number of variables to improve the methodology and weighing the advantages of each against their ease of implementation, ambient temperature was found to be more suitable than any of the alternative parameters for optimizing cement overdosing in concrete in the summertime.

Consequently, an automated real-time ambient temperature measuring system was installed. This eliminated the need to correlate cement overdosing to the time intervals. This system provides for direct optimization of cement overdosing in concrete depending on the ambient temperature during batching.

\section{FINDINGS}

After the methodology was implemented, a statistical analysis was performed of the compressive strength values for quality control cylindrical specimens made by a number of ready mix concrete plants in Catalonia, to verify the results.

The parameters studied in connection with concrete compressive strength included: number of samples, mean strength, estimated characteristic strength, standard deviation, coefficient of variation, cement overdosing, total cement proportioning, relative savings in cement and slump. Of these, only mean concrete compressive strength is discussed in the present paper. 


\subsection{Resultados obtenidos en las plantas de producción piloto}

A continuación, se muestran en la Figura 7 los resultados obtenidos en algunas de las plantas de producción de hormigón preparado (Maresme, Vallés Oriental y Baix Llobregat), las cuales fueron las plantas piloto en donde se implementó por primera vez la metodología desarrollada a partir de mediados del mes de julio de 2005; estos resultados están expresados en porcentaje respecto a la resistencia característica del hormigón a los 28 días. La elección de estas tres plantas como piloto, se debió a que su ubicación geográfica corresponde a zonas de clima mediterráneo, en cuyas características se basó el planteamiento metodológico inicial.

\subsection{Findings for pilot production plants}

Figure 7 shows the results for some of the ready mix concrete plants (Maresme, Vallés Oriental and Baix Llobregat), which served as pilot plants in which the methodology was first implemented, beginning in July 2005; these results are given as a per cent of 28-day characteristic strength. The choice of these three plants for the pilot study was due to their location in areas with a Mediterranean climate on which the initial approach was based.

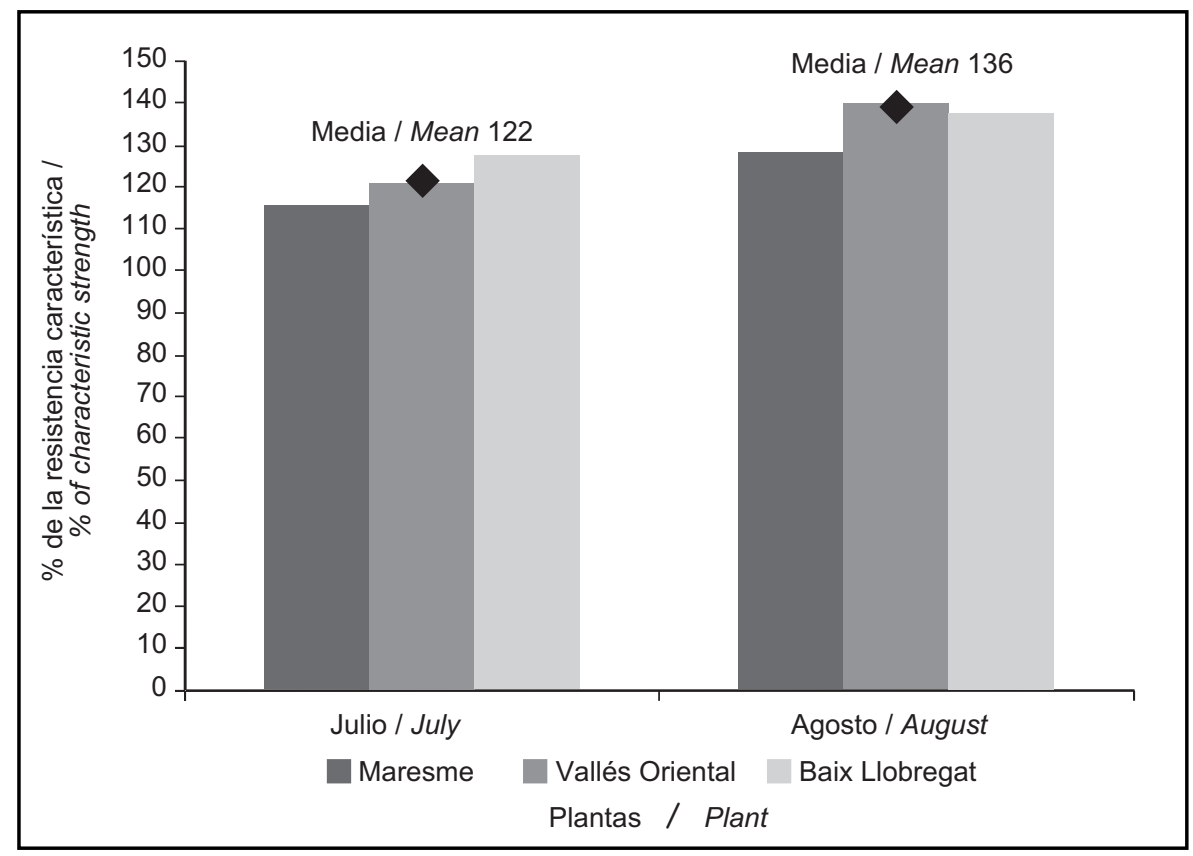

Figura 7. Resistencias medias a los 28 días en algunas plantas de hormigón en el verano de 2005 (en \% referente a la resistencia característica).

Figure 7. Mean 28-day strength for several concrete plants in summer 2005 (in per cent of characteristic strength).

Puede verse en los resultados anteriores, que los valores medios de las resistencias superan el $120 \%$ y ninguno de éstos es inferior al $90 \%$ (0,9*fck), cumpliendo adecuadamente los requerimientos de la Instrucción de Hormigón Estructural EHE (10). Para el caso de los coeficientes de variación, en general pueden considerarse aceptables, ya que en todos los casos son menores o iguales al $13 \%$, considerando un proceso industrial con consumos de cemento variables.

\subsection{Generalización y continuidad de la metodología}

La metodología desarrollada se siguió implementando en otras plantas de producción a parte de las piloto, en las cuales siguió dando resultados muy satisfactorios en
The above findings, with mean strength values upward of $120 \%$ of the characteristic strength in some case and none lower than the $90 \%$ lower limit $(0,9 *$ fck) laid down in the EHE concrete structural code, made these concretes fully code-compliant (10). The coefficients of variation were also acceptable as a rule, for they were consistently lower than 13\%, despite the industrial context and varying proportions of cement.

\subsection{Generalization and continuation of the methodology}

In light of the generally satisfactory results recorded for the pilot plants, the methodology was implemented in other production plants. The resulting mean values 
general. En este sentido, a manera de ejemplo se muestran en la Tabla 4 los resultados promedio obtenidos en algunas de las plantas de producción de hormigón preparado agrupadas por comarcas: Maresme, Baix Llobregat y Barcelonés, correspondientes al verano de 2007; estos resultados están expresados en porcentaje respecto a la resistencia característica del hormigón a los 28 días. obtained in the summer of 2007 for some of the ready mix plants are given in Table 5 by county: Maresme, Baix Llobregat and Barcelonés, in per cent of the 28-day characteristic concrete strength.

Tabla 4 / Table 4

Resistencias medias a los 28 días en algunas plantas de hormigón en el verano de 2007 (en \% referente a la resistencia característica). Mean 28-day strength for concrete plants in summer 2007 (in per cent of characteristic strength).

\begin{tabular}{|c|c|c|c|c|c|}
\hline \multicolumn{7}{|c|}{ Medias de resistencia a compresión a 28 días / 28-day compressive strength (\%) } \\
\hline Planta / Mes / Plant / month & Junio / June & Julio / July & Agosto / August & Septiembre / September & Media / Mean \\
\hline Maresme & 126 & 128 & 123 & 129 & 127 \\
\hline Baix Llobregat & 132 & 136 & 129 & 133 & 133 \\
\hline Barcelonés & 129 & 124 & 125 & 134 & 128 \\
\hline Media & 129 & 129 & 126 & 132 & 129 \\
\hline
\end{tabular}

De igual forma, puede verse en los resultados anteriores que los resultados de resistencia media a compresión obtenidos, son superiores $120 \%$, lo que garantiza el adecuado cumplimiento de los estándares de control de calidad. Asimismo, puede verse que la fluctuación de valores es pequeña y que en general muestra una adecuada estabilidad en el tiempo.

Por otro lado, se muestran en la Figura 8 los resultados obtenidos en algunas de las plantas de producción de hormigón preparado (Barcelonés, Maresme, Vallés
The above findings showed that the mean compressive strength values obtained were upward of $120 \%$ of the characteristic value, guaranteeing due compliance with quality control standards. Moreover, the fluctuation in values was small and suitably stable over time, as a rule.

Figure 8 , in turn, shows the findings for some ready mix concrete plants (Barcelonés, Maresme, Vallés Oriental, Baix Llobregat, Vallés Occidental and Barcelonés) in the

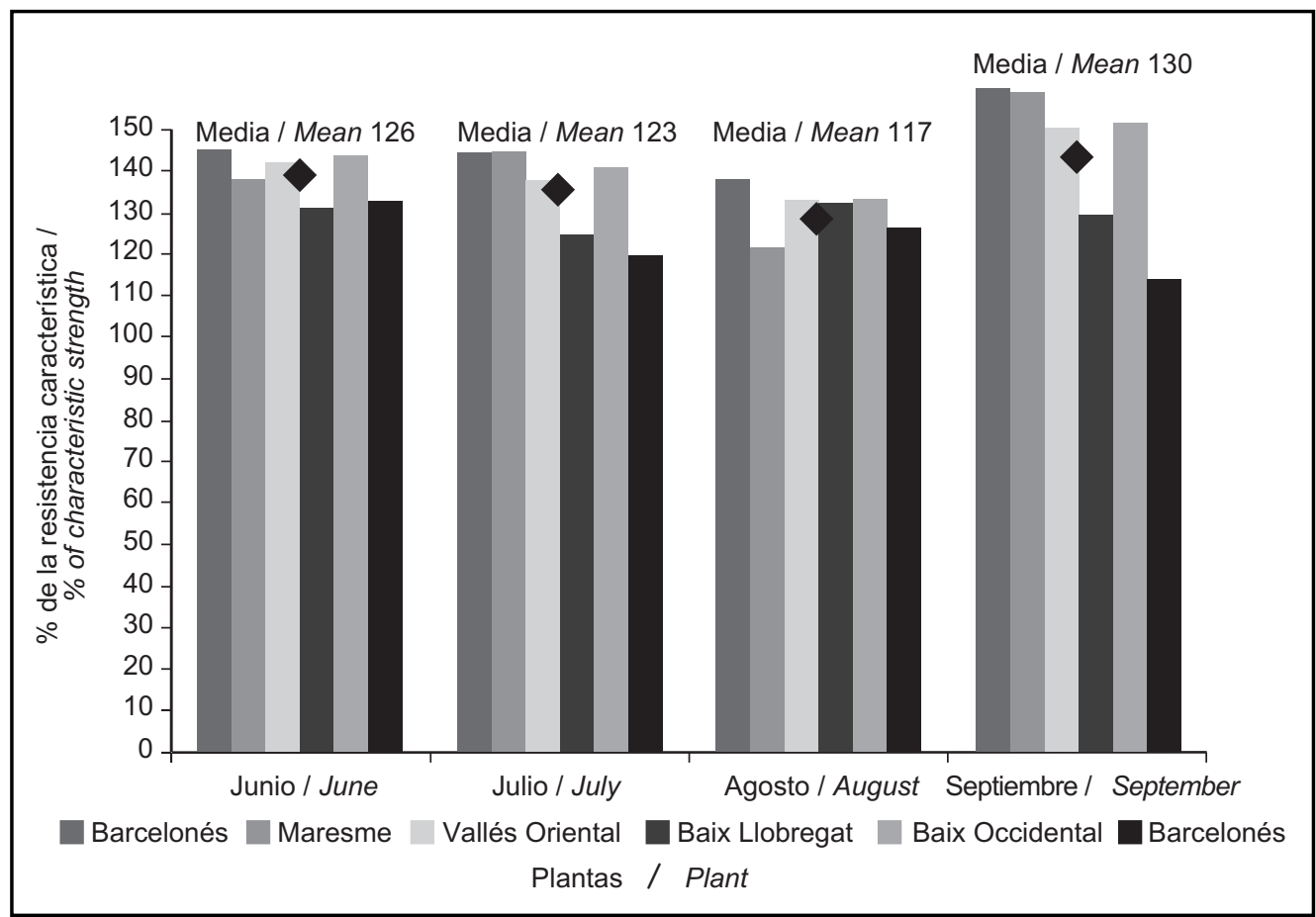

Figura 8. Resistencias medias a los 28 días en algunas plantas de hormigón en el verano de 2008 (en \% referente a la resistencia característica).

Figure 8. Mean 28-day strength for several concrete plants in summer 2008 (in per cent of characteristic strength). 
Oriental, Baix Llobregat, Vallés Occidental y Barcelonés) correspondientes al último verano (2008); de igual forma estos resultados están expresados en porcentaje respecto a la resistencia característica a los 28 días.

Al igual que en los resultados de los años anteriormente presentados, los resultados obtenidos en las plantas de producción de hormigón en el verano de 2008 muestran las mismas tendencias, en el sentido de que los valores de resistencia media a compresión son todas superiores al $110 \%$ y que, en general, muestra una adecuada estabilidad en el tiempo.

También puede observarse que en el mes de septiembre la resistencia promedio es mayor que en los meses anteriores, lo cual probablemente se deba a que las temperaturas ambientales comienzan a bajar y la resistencia del hormigón no disminuya tanto. Asimismo, los valores medios de resistencia obtenidos durante los meses de verano en estos últimos años muestran una tendencia más o menos similar a la del resto de los meses del año, lo cual pone de manifiesto el buen funcionamiento de dicha metodología.

Por último, en ningún caso se sobrepasó la máxima relación agua/cemento ni se reduce el contenido mínimo de cemento especificado por la Instrucción de Hormigón Estructural EHE (10), lo que garantiza la adecuada durabilidad de estos hormigones.

\section{CONCLUSIONES}

Como conclusiones principales del presente trabajo se pueden mencionar las siguientes:

- La metodología desarrollada ha funcionado con éxito en todas las plantas de producción de hormigón preparado en las que fue implementada industrialmente, ya que el consumo de cemento en el hormigón puede ser optimizado sin causar detrimentos en las prestaciones del mismo, lo que permite reducir costes de producción sin castigar la calidad del producto.

- Los valores de resistencia media obtenidos de los hormigones fabricados en verano bajo los criterios de la metodología desarrollada, cumplen con la normativa EHE en relación a resistencia característica estimada, máxima relación agua/cemento y contenido mínimo de cemento. Asimismo, la dispersión obtenida en resultados a compresión es muy aceptable, ya que en todas las plantas los coeficientes de variación fueron inferiores al $11 \%$.

- Los parámetros alternativos estudiados: humedad relativa, presión atmosférica e incrementos y decrementos de temperatura ambiental, no aportan ventajas summer of 2008, likewise given as percentages of 28day characteristic strength.

The findings for the ready mix plants in the summer of 2008 followed the same pattern as above: the mean compressive strength values were over $110 \%$ greater than the characteristic value and suitably stable over time, generally speaking.

Mean strength was also found to be higher in September than in the preceding months, very likely because ambient temperatures had begun to decline. Furthermore, the mean strength values found in the summer months in the last few years were similar, by and large, to the values for the other months of the year, confirming the effectiveness of the method.

Lastly, the maximum water/cement ratio was not exceeded in any case, nor was the cement content lower than the minimum specified in the Spanish structural concrete code (10). These conditions guarantee the durability of the concrete involved.

\section{CONCLUSIONS}

The main conclusions to be drawn from the present study include:

- The methodology developed proved to be successful in all the ready mix concrete plants where it was industrially implemented, where the proportion of cement in concrete has been optimized with no adverse effects on the end product, i.e.: lowering costs without jeopardizing quality.

- The mean strength values for the concrete made in the summertime in accordance with the methodology developed were code EHE-compliant in terms of the estimated characteristic strength, maximum water/cement ratio and minimum cement content. The dispersion in the compressive strength values was also highly acceptable, with a coefficient of variation of under $11 \%$ in all the plants.

- No additional advantage was derived from using any of the alternative parameters studied - relative humidity, atmospheric pressure or rises or declines in 
añadidas como parámetros de control para la optimización de la sobredosificación de cemento en el hormigón, en relación al control mediante la temperatura ambiental.

\section{AGRADECIMIENTOS}

Los autores de este artículo desean expresar su agradecimiento al Dr. Luis Agulló Fité por su ayuda durante toda la realización del trabajo y al personal técnico del Laboratorio de Tecnología de Estructuras (LTE) de la Universitat Politècnica de Catalunya (UPC), especialmente a Tomàs García Vicente. Asimismo, el autor José A. Ortiz Lozano agradece el apoyo brindado por la Universidad Autónoma de Aguascalientes (UAA) y el Programa de Mejoramiento del Profesorado (PROMEP) de México. ambient temperature - as parameters for monitoring the optimization of cement overdosing in concrete.

\section{BIBLIOGRAFÍA / BIBLIOGRAPHY}

(1) Ortiz Lozano, J. A.; Aguado de Cea, A.; Agulló Fité, L.; García Vicente, T. y Zermeño de León, M. E.: "Estudio experimental sobre la influencia de la temperatura ambiental en la resistencia del hormigón preparado. Bases teóricas", Mater. Construcc., vol. 58, no 291 (2008), pp. 7-22. doi:10.3989/mc.2008.v58.i291.103

(2) Ortiz, J.: "Estudio experimental sobre la influencia de la temperatura ambiental en la resistencia del hormigón preparado". Tesis Doctoral. Universitat Politècnica de Catalunya. Barcelona (2005).

(3) Palomo, A.; Blanco-Varela, M. T.; Vázquez, T.; Puertas, F. y Puig, J.: "Modificaciones microestructurales del cemento hidratado por curado del hormigón en períodos estivales", Cemento-Hormigón, nº 814 (2000), pp. 1004-1018.

(4) Zein Al-Abideen, M. H.: "Concrete practices in the Arabian Peninsula and the Gulf", Materials and Structures, no 31 (1998), pp. 275280. doi:10.1007/BF02480426

(5) Alhozaimy, A. M.: "Effect of retempering on the compressive strength of ready-mixed concrete in hot-dry environments", Cement and Concrete Composites, no 29 (2007), pp. 124-127. doi:10.1016/j.cemconcomp.2006.08.007

(6) López de la Fuente, J. y Palomo, A.: "Comportamiento mecánico-resistente del hormigón preparado en períodos estivales", CementoHormigón, no 867 (2004), pp. 4-13.

(7) Elkhadiri, I. y Puertas, F.: "The effect of curing temperature on sulphate-resistant cement hydration and strength", Construction and Building Materials, no 22 (2008), pp. 1331-1341. doi:10.1016/j.conbuildmat.2007.04.014

(8) Martínez-Ramírez, S. y Frías, M.: "The effect of curing temperature on white cement hydration", Construction and Building Materials, artículo en prensa (2008).

9) Al-Khaiat, H. y Nattuhi, N.: "Long-term strength development of concrete in arid conditions", Cement and Concrete Composites, no 23 (2001), pp. 363-373. doi:10.1016/S0958-9465(01)00004-X

(10) Instrucción de Hormigón Estructural EHE-08, Real Decreto 1247/2008 del 18 de julio, Madrid (2008).

(11) Scanlon, J. M.: "Quality control during hot and cold weather", Concrete International, vol. 19, no 9 (1979), pp. 58-65.

(12) Scanlon, J. M.: "Controlling concrete during hot and cold weather", Concrete International, vol. 19, no 6 (1997), pp. 52-58.

(13) Ravina, D. y Soroka, I.: "Admixture effects on hot-weather concrete", Concrete International, vol. 24, no 5 (2002), pp. 34-38.

(14) Ait-Aider, H.; Hannachi, N. E. y Mouret, M.: "Importance of W/C ratio on compressive strength of concrete in hot climate conditions", Building and Environment, no 42 (2007), pp. 2461-2465. doi:10.1016/j.buildenv.2006.05.003

(15) Al-Negheimish, A. I. y Alhozaimy, A. M.: "Impact of extremely hot weather and mixing method on changes in properties of ready mix concrete during delivery", ACI Materials Journal, vol. 105, no 5 (2008), pp. 438-444.

(16) Soroka, I. y Ravina, E.: "Hot weather concreting with admixtures", Cement and Concrete Composites, no 20 (1998), pp. 129-136. doi:10.1016/S0958-9465(98)80005-X

(17) Chongjiang, Du.: "Dam construction - Concrete temperature control using fly ash", Concrete International, vol. 18, no 4 (1996), pp. 34-36.

(18) Soria, E. A. y Rahhal, V. F.: "Influencia de la temperatura de colocación sobre el estado fresco de hormigones elaborados con cemento fillerizado y compuesto", Mater. Construcc., vol. 53, no 271-273 (2003), pp. 27-36.

(19) Kayyali, O. A.: "Effect of certain mixing and placing practices in hot weather on the strength of concrete", Building and Environment, vol. 19, no 1 (1984), pp. 59-63. doi:10.1016/0360-1323(84)90015-5 
(20) Aitcin, P. C.: "Cements of yesterday and today concrete of tomorrow", Cem. Concr. Res., no 30 (2000), pp. $1349-1359$. doi:10.1016/S0008-8846(00)00365-3

(21) Flower, D. J. M. y Sanjayan, J. G.: "Green house gas emissions due to concrete manufacture", Int J LCA, vol. 12, no 5 (2007), pp. 282-288. doi:10.1065/lca2007.05.327

(22) Ortiz, J. A.; Aguado, de Cea, A.; Agulló, L. y García, T.: "Ready mix concrete optimization for hot weather climates", Memorias del $2^{\text {nd }}$ International FIB Congress (Fédération Internationale du Beton), ID 13-39, Nápoles, Italia (2006).

(23) Calmon, J. L.: "Estudio térmico y tensional en estructuras masivas de hormigón. Aplicación a las presas durante la etapa de construcción". Tesis Doctoral. Universitat Politècnica de Catalunya, Barcelona (1995).

(24) www.meteocat.com, Servei Meteorològic de Catalunya, Departament de Medi Ambient, Generalitat de Catalunya.

(25) Dos Santos, A. C. P.: "Caracterización de las propiedades de hormigones autocompactantes asociadas al esqueleto granular". Proyecto de Tesis Doctoral. Universitat Politècnica de Catalunya. Barcelona (2006). 